\title{
Endophytic Microorganisms Isolated of Plants Grown in Colombia: A Short Review
}

Hernando José Bolívar-Anillo1,2*, Christian J. Orozco-Sanchez ${ }^{3}$, Gesiane da Silva Lima ${ }^{4}$ and Gabriel Franco dos Santos ${ }^{4}$

${ }^{1}$ Laboratorio de Investigación en Microbiología, Programa de Microbiología, Facultad de Ciencias Básicas y Biomédicas, Universidad Simón Bolívar, Barranquilla, Atlántico, Colombia

${ }^{2}$ Departamento de Química Orgánica, Facultad de Ciencias, Universidad de Cádiz, Campus de Puerto Real, España

${ }^{3}$ Facultad De Ciencias Económicas, Fundación Tecnológica Antonio de Arévalo, Cartagena, Bolívar, Colombia

${ }^{4}$ Departamento de Química, Instituto de Ciências Exatas, Universidade Federal de Minas Gerais, Belo Horizonte, MG, Brazil

\begin{abstract}
Colombia is listed as the second largest country in plant diversity in the world, presenting more than 6000 species of endemic plants. The different genus and species of plants, as well as the various environments encountered in the country, are responsible for the countless amount of endophytic bacteria and fungi. So far, only a few endophytic microorganisms were isolated in Colombia, including the genera Pseudomonas, Burkholderia, Chromobacterium, Curtobacterium, Acremonium, Alternaria, Aspergillus and Fusarium, which have been isolated from rice, coffee, rose, grass and Espeletia plants. Fungi and bacteria isolated from these plants have great potential for use in biocontrol, bioremediation and in promoting plant growth. Colombia for its rich flora have become a promising country for finding new microorganisms associated with plants, especially those with potential for food industry, pharmaceuticals and agriculture.
\end{abstract}

Keywords: Endophytic microorganisms; Fungi; Bacteria and Colombia

\section{Introduction}

Colombia has the second largest biodiversity in the world, surpassing countries such as Indonesia, China, Mexico, USA and Australia. In the first place, the country with the largest biodiversity is Brazil, which has a considerable larger area than Colombia. According to the Royal Botanical Garden, Colombia is the country with the highest biological richness per $\mathrm{m}^{2}$. From 2000 to 2009, 1,272 new biological species where described there, which represents $0.72 \%$ of new species in the Planet for this period [1-4]. In relation to its rich flora, Colombia is the second country with more diversity in plants, featuring 1,500 exclusive species. Moreover, it is the richest in ferns, mosses and lichens at neotropical level [2]. Plants establish relations with a range of microorganisms in different ways, some of them being endophytes. Unlike pathogens and opportunistic microorganisms, the endophytes live inside plant tissues without causing any damage [3,5]. Endophytes and plants live in symbiosis with mutual benefits. While the plant provides nutrients for the development of microorganisms, they help to promote plant growth by different mechanisms (nitrogen fixation, phosphate solubilization, iron chelation and hormone levels modulation) pathogen resistance herbivore defense and others [6-10].

There are about 300,000 species of plants and each can host one or even more species of endophytic microorganisms [11]. However, only a few have been thoroughly studied in relation to their endophytic microbiota. Therefore, finding new and beneficial endophytic microorganisms in this diversity of plants and ecosystems is highly likely [12]. These microorganisms showed a great potential for bioremediation, biocontrol, enzyme production, bioactive compounds, new secondary metabolites, plant growth and others [13-19].

In this way, the biological knowledge has the potential to stimulate public interest in biodiversity [20]. Investigation of endophytic microorganisms associated with different species of plants found in Colombia opens doors to new researches to better understand the Colombian microbial biodiversity, to identify new species or establish new genera of bacteria and fungi endophytes and consequently, to explore future applications in different fields [21-23]. This short review summarizes the different genera and species of endophytic bacteria and fungi isolated from plants in Colombia, and their potential in many processes such as biocontrol, bioremediation, biocatalysis and development of new drugs.

\section{Plant biodiversity in Colombia}

With more than 56,000 species recorded in the Global Biodiversity Information Facility (GBIF), Colombia share with Brazil the first place worldwide in terms of biodiversity. The country is ranked by the United Nations Environment Programme as one of the 17 megadiverse countries, hosting $70 \%$ of the world's biodiversity in only $10 \%$ of its territory [24]. Meanwhile, the Information System on Biodiversity (SIB) and the catalog of plants and lichens of Colombia establish that the country has 1,643 species of ferns and related, 262 species of palms, 4010 orchids, 45 species of gymnosperms, 1636 species of mosses and related, and 22840 species of angiosperms known [25,26]. Rangel-Ch conducted an inventory of Colombian flora, considering the geographical pattern of natural regions of Colombia, which led to the establishment of the plant component in the Pacific and Caribbean coast, and in Orinoco, Amazon and Andean regions [4] (Table 1). The Andean region has the largest concentration of biodiversity in Colombia and the Pacific coast has the highest concentration of wealth in flora of humid terrestrial biomes of the world. Meanwhile, the Colombian Paramo represents $60 \%$ of the wealth of flora among the high mountain

*Corresponding author: Hernando José Bolívar-Anillo, Laboratorio de Investigación en Microbiología, Programa de Microbiología, Facultad de Ciencias Básicas y Biomédicas, Universidad Simón Bolívar, Barranquilla, Atlántico, Colombia, Tel: 57 (5) 344 4333; E-mail: hbolivar1@unisimonbolivar.edu.co

Received November 25, 2016; Accepted December 20, 2016; Published December 27, 2016

Citation: Bolívar-Anillo HJ, Orozco-Sanchez, CJ, Lima GS, dos Santos GF (2016) Endophytic Microorganisms Isolated of Plants Grown in Colombia: A Short Review. J Microb Biochem Technol 8: 509-513. doi: 10.4172/1948-5948.1000335

Copyright: (c) 2016 Bolívar-Anillo HJ, et al. This is an open-access article distributed under the terms of the Creative Commons Attribution License, which permits unrestricted use, distribution, and reproduction in any medium, provided the original author and source are credited. 


\begin{tabular}{|c|c|c|c|c|c|}
\hline Flora & $\begin{array}{c}\text { Pacific } \\
\text { coast }\end{array}$ & $\begin{array}{c}\text { Caribbean } \\
\text { coast }\end{array}$ & $\begin{array}{c}\text { Orinoco } \\
\text { region }\end{array}$ & $\begin{array}{c}\text { Amazon } \\
\text { region }\end{array}$ & $\begin{array}{c}\text { Andean } \\
\text { region }\end{array}$ \\
\hline $\begin{array}{c}\text { Species of flowering } \\
\text { plants }\end{array}$ & 4,525 & 4,274 & 4,347 & 11,500 & 7,600 \\
\hline Species of ferns & 425 & 386 & 254 & 1050 & 510 \\
\hline Species of moss & 132 & 230 & 86 & 800 & 174 \\
\hline Species of lichens & 189 & 379 & 130 & 1,300 & 322 \\
\hline Species of liverworts & 170 & 182 & - & 756 & 100 \\
\hline
\end{tabular}

Table 1: Number of species of Colombian plants.

biome of Central and Northern South America.

The geographical position, the influence of two seas, the climate variability and topography are reasons that could explain the rich flora of Colombia [2,4]. Although there are records of some biological groups as birds, other groups are still poorly documented. Among the taxonomic groups underrepresented in the data portal SIB there are mainly viruses, bacteria, protozoa and fungi.

\section{Endophytic bacteria isolated from plants grown in Colombia}

Rice is the third most important product in Colombian agriculture and plays an important role in the diet and feeding of Colombian households [27]. Pérez et al. determined the diversity of endophytic bacteria population associated to different tissues of rice plants and their antimicrobial activity against Burkholderia glumae, a gram negative bacillus responsible for causing grain rot, sheath and rice seedling [28]. The samples analyzed were taken from the genebank of the Experimental Station of Rice Victoria National Fund, located in the municipality of Mocarí, from the department of Cordoba. A total of 89 endophytic bacteria isolates from tissues of the rice plant. Four varieties described as Fedearroz 2000 (F2000), Fedearroz 473 (F473), Fedearroz Mocarí (Fmocarí) and Fedearroz 733 (F733) were studied. The rice varieties with greater population density of endophytic bacteria were F733 and FMocari with $1.77 \times 10^{10}$ and $1.7 \times 10^{10} \mathrm{CFU} / \mathrm{g}$ tissue, respectively, whilst the F273 and F2000 varieties had densities of $2.0 \times$ $10^{7}$ and $1.56 \times 10^{7} \mathrm{CFU} / \mathrm{g}$ tissue. Of the 89 isolated morphotypes, 28 showed antibacterial activity in vitro against B. glumae. Morphotypes isolated of stem showed higher inhibitory activity than morphotypes of roots. Rice varieties with higher density of associated bacteria have a higher tolerance to the disease of bacterial panicle blight, when compared with those with lower count of bacteria endophytes [29]. In this work, we comprise the importance of studying endophytic microorganisms and their potential applications, since one or more of these microorganisms may have secondary metabolites or develop strategies to combat pathogens of host plants, as exemplified above by the 28 endophytes, which presented activity against pathogenic $B$. glumae.

Pérez-Cordero et al studied the resistance to lead in endophytic bacteria isolated from commercial rice varieties. The samples analyzed were obtained from commercial varieties grown in the Experimental Station "La Victoria del Fondo Nacional del Arroz", located in the city of Monteria, Cordoba. A total of 168 morphotypes of endophytic bacteria from roots, leaves and tillers were isolated from the varieties called Fedearroz 2000 (F2000), Fedearroz 473 (F473), Fedearroz Mocarí (Fmocarí) and Fedearroz 733 (F733). In this study, the highest population density was observed in the root $\left(3.045 \times 10^{10} \mathrm{CFU} / \mathrm{g}\right.$ tissue $)$ compared to tillers $\left(4.35 \times 10^{9} \mathrm{CFU} / \mathrm{g}\right.$ of tissue $)$ and leaves $\left(7.34 \times 10^{8}\right.$ $\mathrm{CFU} / \mathrm{g}$ tissue). The highest bacteria density was observed in the varieties F733 $\left(2.12 \times 10^{10} \mathrm{CFU} / \mathrm{g}\right.$ of tissue $)$ and Fmocarí $\left(2.09 \times 10^{10} \mathrm{CFU} / \mathrm{g}\right.$ tissue) compared to the varieties F2000 $\left(1.56 \times 10^{7} \mathrm{CFU} / \mathrm{g}\right.$ of tissue $)$ and F473 $\left(2.07 \times 10^{7} \mathrm{CFU} / \mathrm{g}\right.$ tissue $)$. Among all the morphotypes isolated, only two were able to grow in different concentrations of $\mathrm{Pb}\left(\mathrm{NO}_{3}\right)_{2}$; which were identified as Pseudomonas putida and Burkholderia cepacia by the gallery system API20E and compared to BioMerieux database, St Louis, MO, USA. The morphotype identified as $P$. putida showed higher growth in treatments with $\mathrm{Pb}$ than $B$. cepacia [30].

Another example is the Colombian coffee, which is recognized worldwide for their superior quality product and one of the best in the world in terms of aroma and flavor. The Colombian coffee area corresponds to approximately 869,158 hectares and 566,000 families engaged in cultivation. Around one million people are economically dependent on the process-related activities, marketing and export of coffee. This agricultural and industrial activity always had a significant economic importance in the country, representing $4 \%$ of the total GDP in the last decade [31]. Vega and contributors isolated endophytic bacteria in stem, leaves and berries of Coffea arabica $L$. collected in Colombia, Hawaii and Mexico. Colombia samples were obtained from the National Coffee Research Center, CENICAFE, Chinchiná, city of Caldas department. Among the 87 endophytic bacteria isolated in this study, 67 were isolated from coffee plants grown in Colombia, which belong to the genera Bacillus, Burkholderia, Cedecea, Chromobacterium, Curtobacterium, Enterobacter, Escherichia, Klebsiella, Methylobacterium, Pseudomonas, Serratia, Stenotrophomonas and Variovorax. The different bacterial genera associated with coffee plants allow the development of new researches in the sense of to determine the interactions between endophytic bacteria, their host plants and others endophytes, production of metabolites, among others [32].

The grass "Colosoana" (Bothriochloa pertusa) has colonized most of Colombian grasslands, and despite its immature leaves have crude protein levels of $12 \%$ and digestibility of 60 to $70 \%$, they areconsidered by some farmers as an undergrowth vegetation [33]. Perez et al analyzed the endophytic flora of grass grown on cattle farms located in the municipalities of Corozal, Sampués and Tolu in Sucre, Colombia. The population density for endophytic bacteria isolated from Colosuana grass roots ranged from 3.1 to $6.7 \times 10^{5} \mathrm{CFU}, 4.2$ to $6.7 \times 10^{5} \mathrm{CFU}$ and 3.2 to $5,0 \times 10^{5} \mathrm{CFU}$ for the Corozal, Sampués and Tolu samples, respectively. The study showed no significant differences between total CFU. Moreover, the highest density of isolated endophytic bacteria was found in Sampués [34].

\section{Endophytic fungi isolated from plants grown in Colombia}

The flower industry in Colombia emerged facing the external market, and it is the most important production of non-traditional exports in the country. Colombia ranks the second in the world in the export of flowers, only behind the Netherlands [35]. The flower production is mainly based on carnations and roses, which are the most extensive and diversified cultures [36]. Salgado Salazar et al isolated some endophytes from the rose (Rosa hybrida) leaves grown in urban Bogota, and in the northeastern and northwestern areas. From the 560 sub-fragments of leaves inoculated in culture media, only 92 were colonized by endophytes. By conventional methods using taxonomic keys, 31 isolates were identified to genus or species. Among the isolated genera were described Acremonium, Alternaria, Aureobasidium, Cladosporium, Chaetomium, Gliocladium, Nigrospora, Nodulisporium, Phoma, Xylaria and Coelomycete. The lower number of isolates obtained, when compared to the other studies, could be related to the characteristics of the investigated plants, not being native and located in this particular case, in the city of Bogota, a completely urbanized area with high levels of air pollution. Endophytes reported here may have a great potential 
for the future tests of antagonism against plant pathogens [37].

Colombia has 4,270 registered species of orchids, of which 1,572 are unique to the country. Their great diversity coupled with the beauty of their-flowers have made their cultivation and exportation commercially and economically interesting for the country $[38,39]$. Lizarazo-Medina et al. determined that the diversity and the composition of the endophytic mycobiota from leaves and roots of Cattleya percivaliana and Cattleya trianaei grown in the greenhouse El Cerro of the Colombian Orchid Society, located in Fredonia (Antioquia), Colombia. They were isolated a total of 323 fungi species from 1,200 fragments of leaves and roots. These species were classified taxonomically considering the macroscopic and microscopic characters in 14 genera and five morphotypes. Fungal isolates belong to the genera Colletotrichum, Fusarium, Sclerotium, Botryotrichum, Aureobasidium, Chromelosporium, Gonatobotrys, Monilinia, Cladosporium, Curvularia, Gloeosporium, Trichoderma, Exophiala and Nodulisporium. Fusarium was the most abundant in roots for all species, while in the leaves the most abundant were Colletotrichum and Sclerotium [39]. Ordóñez et al isolated and identified root endophytes in orchids of Vanilla genus in the wild, in order to determine their effect on the growth of V. planifolia plants when inoculated into the substrate. Vanilla sp. plants were collected in the Gulf of Morrosquillo and Montes de Maria (Sucre), Sierra Nevada de Santa Marta (Magdalena), San Pedro de Uraba, San Luis, San Jeronimo and Porce (Antioquia), Yopal (Casanare), Serrania de la Macarena (Caquetá) and Buenaventura (Valle del Cauca). By sequencing the ITS regions, the fungi were identified as Ceratobasidium, Phomopsis, Hypoxylon, Xylariaccae, Phoma, Trichoderma and Bipolaris. Biomass and growth of orchid plants inoculated with different isolated fungi showed significant differences for the variables height, root length, root mass and leaf mass, which highlights the importance of these fungi in the protection and improvement of nutrition in these plants [40].

Phosphorus $(\mathrm{P})$ is an essential macronutrient for the growth and development of plants. Microorganisms play a key role in the cycle of $\mathrm{P}$, in particular, on the release of its organic and inorganic forms through solubilization and mineralization $[41,42]$. Perez et al isolated fungi that were capable of solubilizing phosphates from Colosuana grass root grown on cattle farms located in Sincé, Sucre, Colombia. A total of 43 morphotypes of endophytes were isolated and determined by taxonomic keys: 36 from Deuteromycetes genus, three from Penicillium, two Aspergillus niger, one Zygomycetes and one Paecilomyces. The genera of isolated fungi with phosphate solubilizing activity were identified as Aspergillus, Penicillium and Paecillomyces [43].

Vega et al studied the diversity of endophytic fungi of plants grown coffee in Colombia, Hawaii and Puerto Rico. The Colombia samples were taken at the National Coffee Research Center CENICAFE located in Chinchiná, Caldas. A total of 843 endophytic fungi were isolated, of which 267 were obtained from plants cultivated in Colombia (32\%). Colombian isolates contained 113 genotypes, a plurality (Fisher's alpha) of 75.3 and the dominant genotype was Colletotrichum sp. In addition, they were isolated Agaricomycetes sp., Ascomycota sp., Aspergillus sp., Beauveria sp., Botryosphaeria sp., Cercospora sp., Cladosporium sp., Clonostachys cf. rosea, Colletotrichum sp., Exobasidiomycetes sp., Fusarium sp., Hymenochaetaceae sp., Hypocreales sp., Neosartorya sp., Paecilomyces sp., Penicullium sp., Petriella sp., Pezizomycotina sp., Phomopsis sp., Pleosporaceae sp., Pleosporales sp., Pseudozyma sp., Sordariales sp., Sordariomycetes sp., Sporobolomyces sp., Stereum sp., Tilletia, Trametes sp., Trichoderma sp., Xylaria sp., Xylariaceae sp. and Xylariales sp. Genotypes isolated from plants grown coffee in Colombia among of the exclusive fungi endophytes of only single tissue [44]

\begin{tabular}{|c|c|c|}
\hline Fungi & Number of genotype & \multirow{2}{*}{ Tissue } \\
\hline Aspergillus fumigatus & 1 & \multirow{2}{*}{ Leaves } \\
\hline Bauveria sp. & 1 & \\
\hline Clonostachys cf. Rosea & 1 & \multirow{2}{*}{ Steam } \\
\hline Colletotrichum $\mathrm{sp}$. & 4 & \\
\hline Aspergillus $\mathrm{sp}$. & 1 & \multirow{2}{*}{ Crown } \\
\hline Colletotrichum $\mathrm{sp}$. & 1 & \\
\hline Trichoderma $\mathrm{sp}$. & 1 & Berry \\
\hline Colletotrichum $\mathrm{sp}$. & 1 & \\
\hline Homopsis $\mathrm{sp}$. & 1 & \\
\hline Tilletia sp. & 1 & \\
\hline
\end{tabular}

Table 2: Endophytics fungi from only single tissue of coffee.

(Table 2).

On a previous study, endophytic fungi present in plants of Coffea arabica, Coffea congensis, Coffea dewevrei and Coffea liberica collected in Colombia, Hawaii and Maryland were isolated by Vega et al. [45]. The samples analyzed consisted of leaves, roots, stem and various parts of the coffee berry (crown, peduncle, pulp and seeds). Thirteen Penicillium endophytic species were isolated from Coffea arabica during the study. In the Colombian samples, the isolated species found were Penicillium brevicompactum, $P$. brocae, $P$. oxalicum, all from leaves of plants grown in CENICAFE located in Chinchiná, Caldas. The fungus $P$. oxalicum produces ochratoxin $\mathrm{A}$, however, does not pose a risk to human health because of the amount produced is very low $(0.037 \mathrm{ppb})$. The fact that none of the Penicillium species are reported as pathogens of Coffea spp. implies that these endophytes are not latent pathogens, suggesting commensal relationships or mutuals with coffee plants [45].

Seeds can benefit from microorganisms associated with it, which can play a key role in their preservation and preparation of the medium for germination [46-48]. Seed endophytes are transmitted from generation to generation, thereby ensuring the benefits related to the promotion of growth and biocontrol for future plants [48]. Endophytes of green coffee beans from Guatemala, Colombia, India, Kenya, Papua New Guinea, Puerto Rico and Vietnam were isolated by Vega et al. A total of 19 isolates were obtained during the study; three were isolated from seeds from Colombia and were identified as Aspergillus tubingiensis, Penicillium sp. and Gibberella olsonii [49].

Miles et al isolated endophytic fungi from two species of Espeletia (Asteraceae): Espeletia grandiflora and Espeletia corymbosa, endemic plants of Cruz Verde Paramo, Colombia. The biocontrol ability of the isolated fungi against phytopathogenic fungi was evaluated. A total of 60 endophytic fungi were isolated and identified morphologically in 13 genera: Aureobasidium, Beauveria, Chaetomium, Cladosporium, Epicoccum, Fusarium, Leptosphaerulina, Nigrospora, Paecilomyces, Penicillium, Scopulariopsis, Stemphylium and Trichoderma. In addition, isolates were molecularly identified to species level in the following genera (Table 3).

All isolated fungi were tested in biocontrol and many species showed biological activity against several bacterial, fungal and oomycete plant pathogens. In addition, this work demonstrates that the bioactive metabolites are not only produced in the presence of the plant pathogen. This work showed that the two plant species may be sources of numerous microorganisms, which in turn may be sources of a range of bioactive compounds [50].

The plants studied in Colombia related to endophytic microorganisms are illustrated (Figure 1). 


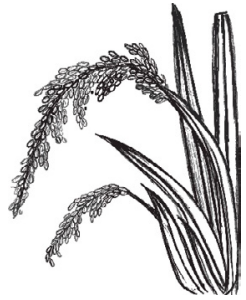

Oryza sativa L Pseudomonas putida Burkholderia cepacia



Coffee bean

Aspergillus tubingiensis, Gibberella sp. Penicillium olsonii

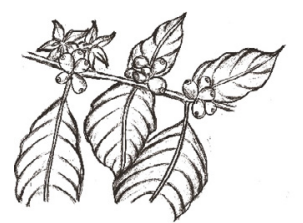

Coffea arabica L

Bacillus, Burkholderia, Cedecea, Chromobacterium, Curtobacterium, Enterobacter, Escherichia, Klebsiella, Methylobacterium, Pseudomonas and Serratia Colletotrichum, Aspergillus sp., Beauveria sp., Botryosphaeria sp., Cercospora sp., Cladosporium sp. Clonostachys cf. rosea, Exobasidiomycetes sp. and Fusarium sp.

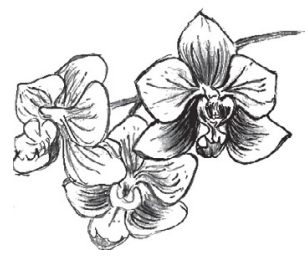

Orchidaceae

Colletotrichum, Fusarium, Sclerotium, Botryotrichum, Aureobasidium, Chromelosporium, Gonatobotrys, Monilinia, Cladosporium, Curvularia, Gloeosporium, Trichoderma, Exophiala y Nodulisporium



Bothriochloa pertusa Aspergillus, Penicillium and Paecillomyces

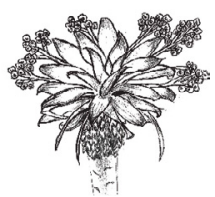

Espeletia grandiflora and Espeletia corymbosa

Diaporthe phaseolorum, Nigrospora oryzae, Diaporthe phaseolorum, Nigrospora oryzae, Beauveria bassiana, Fusarium proliferatum,
Epicoccum nigrum, Eutypella scoparia, Scopulariopsis brevicaulis, Chaetomium globosum and Trichoderma asperellum

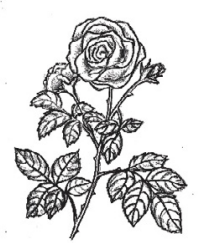

Rosa hybrida

Acremonium, Alternaria, Aureobasidium, Cladosporium, Chaetomium, Gliocladium,

Nigrospora, Nodulisporium, Phoma, Xylaria and Coelomycete

Figure 1: Endophytic microorganisms isolated from plants grown in Colombia

\begin{tabular}{|c|c|}
\hline Fungi & Number of isolates \\
\hline Diaporthe phaseolorum & 22 \\
\hline Nigrospora oryzae & 15 \\
\hline Beauveria bassiana & 12 \\
\hline Fusarium proliferatum & 9 \\
\hline Epicoccum nigrum & 4 \\
\hline Eutypella scoparia & \\
\hline Scopulariopsis brevicaulis \\
Chaetomium globosum \\
Trichoderma asperellum & 3 \\
\hline Aporospora terricola & \\
Cladosporium tunuissimum & \\
Hypoxylon stygium & \\
Leptodontidium orchidicola & \\
Leptosphaerulina chartarum & \\
\hline Aureobasidium pullulans \\
Bipolaris sorghicola \\
Botrytis fabae \\
Cladosporium cladosporioides \\
Coprinellus micaceus \\
Curvularia oryzae \\
Eucasphaeria capensis \\
Paecilomyces sinensis \\
Paraconiothyrium sporulosum \\
Pestalotiopsis disseminata \\
Phoma glomerata \\
Penicillium commune \\
Stemplylium vesicarium \\
Trichoderma atroviride \\
Xylaria polymorpha
\end{tabular}

Table 3: Endophytic fungi isolated from two species of Espeletia (Asteraceae).

\section{Conclusion}

In this short review, we could relate the great biodiversity of plants and endophytic microorganisms available in Colombia to be studied and mainly the few existing studies on these endophytes. Colombia has a wide variety of climates and environments, being bathed by the Pacific Ocean coast and the Caribbean coast, with countless native plants. This review presents its vast unexplored biodiversity and encourages a deeper look at these unstudied microorganisms, which can hide solutions for various diseases, pathogens and industrial processes.

\section{References}

1. Arbeláez-Cortés E (2013) Describiendo especies: Un panorama de la biodiversidad colombiana en el ámbito mundial. Acta biol Colomb 18:165-178.

2. Berg G (2009) Plant-microbe interactions promoting plant growth and health Perspectives for controlled use of microorganisms in agriculture. Appl Microbiol Biotechnol 84: 11-18.

3. Chebotar VK, Malfanova NV, Shcherbakov AV, Ahtemova GA, Borisov AY, et al. (2015) Endophytic bacteria in microbial preparations that improve plant development (Review). Appl Biochem Microbiol 51: 271-277.

4. Rangel-Ch JO (2015) La biodiversidad de Colombia: Significado y distribución regional. Rev acad colomb cienc exact fis nat 39: 176-200.

5. Rosenblueth M, Martínez-Romero E (2006) Bacterial endophytes and their interactions with hosts. Mol Plant-Microbe Interact 19: 827-837.

6. Santoyo G, Moreno-Hagelsieb G, Orozco-Mosqueda M, Glick B (2016) Plant growth-promoting bacterial endophytes. Microbiol Res 183: 92-99.

7. Wu L, Ren A, Jing Y, Zhou Y, Wang X, et al. (2016) Endophytic benefit for 
Citation: Bolívar-Anillo HJ, Orozco-Sanchez, CJ, Lima GS, dos Santos GF (2016) Endophytic Microorganisms Isolated of Plants Grown in Colombia: A Short Review. J Microb Biochem Technol 8: 509-513. doi: 10.4172/1948-5948.1000335

a competitive host is neutralized by increasing ratios of infected plants. Acta Oecol 70: 112-120.

8. Arnold AE, Mejia LC, Kyllo D, Rojas El, Maynard Z, et al. (2003) Fungal endophytes limit pathogen damage in a tropical tree. Proc Natl Acad Sci U S A 100: $15649-15654$

9. Christian N, Sullivan C, Visser ND, Clay K (2016) Plant host geographic location drive endophyte community in the face of perturbation. Microb Ecol 72: 621-632.

10. Fuchs B, Krischke M, Mueller MJ, Krauss J (2016) Herbivore-specific induction of defence metabolites in a grass--endophyte association. Funct Ecol 1-7.

11. Aly AH, Debbab A, Kjer J, Proksch P (2010) Fungal endophytes from higher plants: A prolific source of phytochemicals and other bioactive natural products. Fungal Divers 41: 1-16

12. Ryan RP, Germaine K, Franks A, Ryan DJ, Dowling DN (2008) Bacteria endophytes: Recent developments and applications. FEMS Microbiol Lett 278: 1-9.

13. Manohari R, Yogalakshmi KN (2016) Optimization of copper (ii) removal by response surface methodology using root nodule endophytic bacteria isolated from Vigna unguiculata. Water Air Soil Pollut 227: 285.

14. Eljounaidi K, Kyu-Lee S, Bae H (2016) Bacterial endophytes as potential biocontrol agents of vascular wilt diseases - Review and future prospects. Bio Control 103: 62-68.

15. Dos Santos GF, Locatelli GO, Coêlho DA, Botelho PS, de Amorim MS, et al (2015) Factorial design, preparation and characterization of new beads formed from alginate, polyphosphate and glycerol gelling solution for microorganism microencapsulation. J Sol-Gel Sci Technol 75: 345-352.

16. Kumar K, Belur PD (2016) New extracellular thermostable oxalate oxidase produced from endophytic Ochrobactrum intermedium CL6: Purification and biochemical characterization. Prep Biochem Biotechnol 46: 734-739.

17. Zheng YK, Qiao XG, Miao CP, Liu K, Chen YW, et al. (2016) Diversity, distribution and biotechnological potential of endophytic fungi. Ann Microbiol 66: 529-542.

18. Sharma D, Pramanik A, Agrawal PK (2016) Evaluation of bioactive secondary metabolites from endophytic fungus Pestalotiopsis neglecta BAB-5510 isolated from leaves of Cupressus torulosa D.Don. 3 Biotech 6:210.

19. Afzal I, Iqrar I, Shinwari ZK, Yasmin A (2016) Plant growth-promoting potentia of endophytic bacteria isolated from roots of wild Dodonaea viscosa $L$. J Plant Growth Regul 1-10.

20. Arbeláez-Cortés E (2013) Knowledge of Colombian biodiversity: Published and indexed. Biodivers Conserv 22: 2875-2906.

21. Castro RA, Quecine MC, Lacava PT, Batista BD, Luvizotto DM, et al. (2014) Isolation and enzyme bioprospection of endophytic bacteria associated with plants of Brazilian mangrove ecosystem. Springer Plus 3: 382.

22. Khan S, Afzal M, Iqbal S, Khan QM (2013) Plant-bacteria partnerships for the remediation of hydrocarbon contaminated soils. Chemosphere 90: 1317-1332.

23. Ludwig-Müller J (2015) Plants and endophytes: Equal partners in secondary metabolite production? Biotechnol Lett 37: 1325-1334.

24. Ministerio de Ambiente y Desarrollo Sostenible de la República de Colombia (2014). 11 de Septiembre: Día nacional de la biodiversidad en Colombia.

25. Sistema de Información sobre Biodiversidad de Colombia (2016) Biodiversidad en Colombia.

26. Real Jardín Botánico de Madrid (2015) Investigadores del Real Jardín Botánico, CSIC participan en la elaboración del catálogo de plantas y líquenes de Colombia.

27. Fedesarrollo (2013) Política comercial para el arroz - Reporte final 58.

28. Ham JH, Melanson RA, Rush MC (2011) Burkholderia glumae: Next major pathogen of rice? Mol Plant Pathol 12: 329-339.

29. Pérez AF, Pérez CR, Chamorro LM (2013) Bacterias endofitas asociadas a cultivo de arroz con actividad antimicrobiana sobre Burkholderia glumae. Rev Asoc Col Cienc Biol 25: 31-40.

30. Pérez-Cordero A, Barraza-Roman Z, Martínez-Pacheco D (2015) Identificación de bacterias endófitas resistentes a plomo, aisladas de plantas de arroz. Agron Mesoam 26: 267-276.
31. Puerta-Quintero GI (2003) Especificaciones de origen y buena calidad del café de Colombia. Avances técnicos Cenicafé 316: 1-8.

32. Vega F, Pava-Ripoll M, Posada F, Buyer JS (2005) Endophytic bacteria in Coffea arabica L. J Basic Microbiol 45: 371-380.

33. Piñeros R, Tobar V, Mora J (2011) Evaluación agronómica y zootécnica de pasto Colosoana (Bothriochloa pertusa) en el trópico seco del Tolima. Rev Colombiana cienc anim 4: 36-40.

34. Perez A, Rojas J, Fuentes J (2010) Diversidad de bacterias endófitas asociadas a raíces del pasto Colosuana (Bothriochloa pertusa) en tres localidades del departamento de Sucre, Colombia. Acta Biol Colomb 15: 219-228.

35. Reina M, Camacho K (2006) La Globalización contrariada. Trabajo, territorio y dominación en la floricultura de la sabana de Bogotá. Rev Colomb Soc 27 127-149.

36. Quirós M (2001) La floricultura en Colombia en el marco de la globalización Aproximaciones hacia un análisis micro y macroeconómico. Revista Universidad EAFIT 37: 59-68.

37. Salgado C, Cepero MC (2005) Aislamiento de hongos endofitos en rosa (Rosa hybrida) en Bogotá, Colombia. Rev Iberoam Micol 22: 99-101.

38. Ministerio de Ambiente y Desarrollo Sostenible de la República de Colombia Universidad Nacional de Colombia (2015) Plan para el estudio y la conservación de las orquídeas en Colombia.

39. Lizarazo-medina PX, Mendoza-salazar MM (2014) Diversidad de la micobiota endófita de Cattleya percivaliana y Cattleya trianaei cultivadas en invernadero. Actual Biol 37: 307-318.

40. Ordóñez NF, Otero JT, Díez-Gómez MC (2012) Hongos endófitos de orquídeas y su efecto sobre el crecimiento en Vanilla planifolia Andrews. Acta Agron 61 : $282-290$.

41. Chen YP, Rekha PD, Arun AB, Shen FT, Lai W, et al. (2006) Phosphate solubilizing bacteria from subtropical soil and their tricalcium phosphate solubilizing abilities. Appl Soil Ecol 34: 33-41.

42. Rodríguez H, Fraga $\mathrm{R}$ (1999) Phosphate solubilizing bacteria and their role in plant growth promotion. Biotechnol Adv 17: 319-339.

43. Perez A, De la Ossa J, Montes D (2012) Hongos solubilizadores de fosfatos en fincas ganaderas del departamento de Sucre. Rev Colombiana cienc Anim 4: $35-45$.

44. Vega FE, Simpkins A, Aime MC, Posada F, Peterson SW, et al. (2010) Funga endophyte diversity in coffee plants from Colombia, Hawai'i, Mexico and Puerto Rico. Fungal Ecol 3: 122-138.

45. Vega FE, Posada F, Peterson SW, Gianfagna TJ, Chaves F (2006) Penicillium species endophytic in coffee plants and ochratoxin a production. Mycologia 98: 31-42.

46. Parsa S, Garcia-Lemos AM, Castillo K, Ortiz V, Lopez-Lavalle LAB, et al. (2016) Fungal endophytes in germinated seeds of the common bean, Phaseolus vulgaris. Fungal Biol 120: 783-790.

47. Chee-Sanford JC, William M, Davis AS, Sims GK (2006) Do microorganisms influence seed-bank dynamics? Weed Sci 54: 575-587.

48. Truyens S, Weyens N, Cuypers A, Vangronsveld J (2015) Bacterial seed endophytes: Genera, vertical transmission and interaction with plants. Environ Microbiol Rep 7: 40-50.

49. Vega FE, Posada F, Aime MC, Peterson, SW, Rehner SA (2008) Fungal endophytes in green coffee seeds. Mycosystema 27: 75-84

50. Miles LA, Lopera CA, González S, de García MC, Franco AE, et al. (2012) Exploring the biocontrol potential of fungal endophytes from an Andean Colombian Paramo ecosystem. BioControl 57: 697-710. 